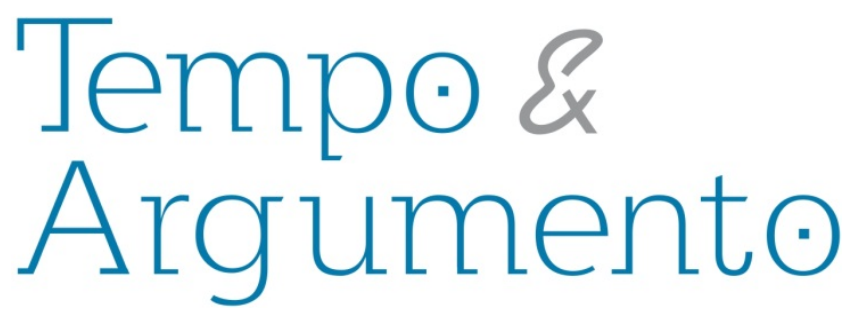

\title{
Quando a Odebrecht construiu Salvador: a narrativa jornalística da história na coleção Terra Brasilis, de Eduardo Bueno (1998-2006)
}

\begin{abstract}
Resumo
O que fabrica o jornalista quando escreve sobre história? Ao subverter a questão clássica de Michel de Certeau (2007), este artigo propõe contribuir para o debate sobre a relação da escrita da história com as amplas audiências. Ao focar em uma análise da principal obra de um dos mais célebres escritores não acadêmicos de livros de história no Brasil Eduardo Bueno com sua coleção Terra Brasilis propõe-se que, entre o trabalho do divulgador e a historiografia profissional, dispõe-se outro ponto de intersecção merecedor de atenção e que responde pelos critérios do "lugar social” do jornalista. É, portanto, a partir de um diálogo com tais referências que percebemos uma narrativa jornalística da história alheia aos mecanismos de mediação próprios da memória disciplinar da historiografia, o que carregaria em si implicações ideológicas (WHITE, 1992) derivadas de querelas do tempo presente.
\end{abstract}

Palavras-chave: Jornalismo. Historiografia. Corrupção. Implicação Ideológica.

\author{
Rodrigo Bragio Bonaldo \\ Doutor em História pela Universidade Federal \\ do Rio Grande do Sul. Professor do \\ Departamento de História da Universidade \\ Federal de Santa Catarina. \\ Brasil \\ rodrigo.bonaldo@ufsc.br
}

\section{Para citar este artigo: \\ BONALDO, Rodrigo Bragio. Quando a Odebrecht construiu Salvador: a narrativa jornalística da história na coleção Terra Brasilis, de Eduardo Bueno (1998-2006). Revista Tempo e Argumento, Florianópolis, v. 9, n. 20, p. 130 -161. jan./abr. 2017.}

\section{DOI: $10.5965 / 2175180309202017130$}

http://dx.doi.org/10.5965/2175180309202017130

\footnotetext{
${ }^{1}$ Este artigo é uma versão bastante modificada do segundo capítulo da dissertação de mestrado intitulada Presentismo e presentificação do passado: a narrativa jornalística da história na 'Coleção Terra Brasilis', de Eduardo Bueno. Porto Alegre. UFRGS. 2010. Agradeço a Temístocles Cezar pela orientação e amizade e ao CNPq pela bolsa de pesquisa.
} 


\title{
When Odebrecht built Salvador: the journalistic account of history in Eduardo Bueno's Terra Brasilis (1998-2006)
}

\begin{abstract}
What does a journalist produces when writing about history? By subverting the classical question posed by Michel de Certeau (2000), this article aims to rehearsal the relationship between the writing of history and broad audiences. For that, we shall focus on a case study of one of its most successful examples in contemporary Brazil: Eduardo Bueno and his Terra Brasilis collection. Between a popular account and a professional historiography we stress the significance of a third important pole of communication. Thus, we propose that Bueno's narrative aims less a representation of the past than a production of its presence (GUMBRECHT,2004), therefore shrugging to the historiographical means of mediation between past and present inscribed in our disciplinary memory and essaying an explanation via ideological implication (WHITE, 1992).
\end{abstract}

Keywords: Journalism. Historiography. Corruption. Ideological Implication.

O que fabrica o jornalista quando escreve sobre história? Transfigura-se magicamente em historiador ou apenas reduz o corpo de explicações a uma interpretação grosseira do passado? Mesmo sem "ir às fontes", debruçando-se entrementes sobre pilhas de produção historiográfica, ele não perde o seu "faro pela notícia". Pretendo atentar neste artigo aos escritos de um dos mais bem-sucedidos representantes do gênero no Brasil. Busco suas relações com a historiografia, também com os entendimentos da comunicação social e, como não poderia deixar de fazê-lo, com a mediação técnica da atividade jornalística ${ }^{2}$.

\footnotetext{
2 Faço uma referência aqui à passagem clássica que marca o início da "operação historiográfica" de CERTEAU, Michel De. A Escrita da História. Rio de Janeiro. Forense Universitária. 2 ed. 2000, p 65. Cito: "O que fabrica o historiador quando 'faz história'? Para quem trabalha? Que produz? Interrompendo sua
} 
Enquanto o Brasil preparava-se para o aniversário dos 500 anos do descobrimento, Eduardo Bueno, repórter, tradutor, editor e autor, já colecionava contatos editoriais, conhecimento do mercado e uma boa capacidade de redação, vantagens que frequentemente são associadas aos jornalistas. O resultado foi a coleção Terra Brasilis, que sem demora revelou-se um best seller. Contar a velha história do descobrimento e dos primeiros anos da colonização brasileira "em ritmo de aventura, graças ao dinamismo da narrativa" garantiu-lhe fama nacional. Foi elogiado por políticos, celebridades, intelectuais e colegas jornalistas, embora tenha recebido críticas vindas, sobretudo, da academia.

Mas qual seria a noção de história por trás dos escritos de Eduardo Bueno? Como veremos, ele defende seus livros a partir do estatuto de uma obra de divulgação. Interessa-se por vazá-los através de uma estrutura narrativa. Fala de personagens concretos, grandes nomes da memória nacional, aventureiros e bandidos, heróis e vilões. Não demonstra a intenção de desenvolver teses, testar hipóteses originais, lançar um novo problema histórico. Com isso, acaso o autor da Terra Brasilis reeditaria uma histoire événementielle nos moldes exatos daquela tão criticada pela tradição dos Annales? Com seus livros abertos, olhos firmes em cada linha, desfrutando suas páginas ao sabor de uma grande aventura, o público estaria consumindo uma versão linguisticamente atualizada - quiçá uma tradução objetiva - da historiografia do século XIX e inícios do XX?

Defender uma tese assim seria como negar o papel da mediação simbólica do comunicador. A prática jornalística, como a historiográfica, possui seus critérios de seleção, maneiras de lidar com o problema da objetividade, algumas regras escritas, outras um tanto silenciosas, seus campos de interesses e suas fórmulas de redação. Mesmo que o trabalho de Eduardo Bueno como vulgarizador historiográfico fuja de padrões do jornalismo diário, as marcas de seu lugar social fazem-se ainda presentes na enunciação da obra que estudo - seja como prescrições de trabalho, seja como atavismos de uma atividade profissional interiorizada.

deambulação erudita pelas salas dos arquivos, por um instante ele se desprende do estudo monumental que o classificará entre seus pares, e, saindo para a rua, ele se pergunta: O que é esta profissão? Eu me interrogo sobre a enigmática relação que mantenho com a sociedade presente e com a morte, através da mediação de atividades técnicas". 
A principal delas - diria a primordial - é a questão do "gancho". Outro jornalistahistoriador, Laurentino Gomes, explica-nos o conceito. No vocabulário das redações essa expressão significaria "motivo ou oportunidade para que uma reportagem seja publicada”. Gomes também alega que chegou a ter sua obra temporariamente cancelada "por falta de gancho" (GOMES, 2007, p. 14). Essa noção permite que um tema, usualmente visto como sendo desprovido de "interesse público", seja atualizado no presente. A aparição ou ausência de um gancho jornalístico, como determinação de um lugar, permite ou proíbe. Traduzido ora como o "obviamente relevante para o tempo presente", ora pela interdição econômico-editorial frente a uma má avaliação do mercado, ele parece ser, tanto para Bueno quanto para Gomes, a característica basilar de suas narrativas jornalísticas da história.

Ao tornar por um instante o passado presente, o gancho cumpre, para o jornalista, a função que o problema historiográfico possui para o historiador acadêmico. O gancho, como código genético de uma escrita da história, coloca o jornalista em uma posição de vantagem econômica em relação ao historiador, aproximando-o do público consumidor.

Nas academias de história existe a figura do orientador ou de uma banca, manifestações discursivas de um saber-poder institucional que "permite ou que proíbe" (CERTEAU, 2000, p. 76-77). No jornalismo, existem os editores, as hierarquias de redação, as redes de solidariedade editoriais e, como não poderia deixar de ser, questões e interesses de ordem essencialmente econômicos. Com eles, o princípio inaugural da narrativa jornalística da história dispõe de mecanismos para integrá-la funcionalmente dentro do mercado editorial de não ficção. Como depois explicaria o próprio Eduardo Bueno:

A coleção foi bolada tendo como gancho os 500 anos. (...) Eu tinha um projeto de escrever sobre história colonial desde 1985. Porém, por uma série de circunstancias da minha carreira, especialmente da minha vida, eu sabia que não era o momento. (...) Quando chegou 1997, eu conclui que sim, tinha chegado a hora. E ela estava vinculada à efeméride. (...) Agora, o fato de sair em 2006 A Coroa, a Cruz e a Espada aconteceu por uma coincidência auspiciosa. Afinal, essa é uma coleção muito auspiciosa, muito bem aventurada, no sentido do mercado. (BONALDO, 2011, p. 132) 
Creio que nas ditas "narrativas jornalísticas da história" - condicionadas como são por regras que as lançam a abordagens de apelo atual - desenvolve-se uma representação do passado que se quer espelho de um suposto "interesse público" do (e pelo) presente. Cabe-nos, então, perguntar quais seriam as implicações historiográficas de uma pulsão de representar o passado tendo em mira esse interesse geral do presente indiciado pela noção de gancho jornalístico.

\section{Critérios de seleção e concepções prévias de notícias}

Muito bem, o jornalista-historiador encontrou seu gancho, teve a ideia certa na ocasião adequada, a editora aprovou a publicação, e então, o que fazer agora, como sua escrita vai representar o passado? Embora não sejam os únicos, os critérios que em tese deveriam garantir a objetividade da comunicação social começam, já se disse, pela noção de "interesse público".

E pelo que, afinal, presa esse interesse público? Pelo que é notícia, naturalmente responderia o jornalista em franco truísmo. A definição desses dois termos, no entanto, passa por alguns critérios difusos. A questão do valor notícia e, dentre elas, dos critérios de noticiabilidade, já pôde ser pautada como problema sociológico. A opinião de que o jornalista trabalha como selecionador de fatos foi desenvolvida ao longo da segunda metade do século $X X$; parte de conclusões realizadas a partir de inúmeros estudos de caso. Afere que os critérios de noticiabilidade, na prática, excedem a dimensão subjetiva dos repórteres e balizam-se, formando zonas-filtro, em um processo ordenado hierarquicamente no cotidiano das redações. A esse fenômeno, a sociologia dos emissores chamou de gatekeeping, ou seja, de acordo com ele, o jornalista funcionaria como uma espécie de porteiro, determinando quais informações são passíveis de se tornarem notícia e quais devem ser descartadas (WOLF, 2005, p.184).

Nos Estados Unidos, o historiador Robert Darnton, que foi jornalista no New York Times, buscou estudar as "determinações culturais profundas" da notícia (DARNTON, 1990, p. 91). Realizou uma análise a partir da sua, digamos, observação participante, na qual mostrou a definição e os critérios de noticiabilidade através das relações construídas 
nas salas de redação. Antes dele, Helen MacGill Hughes conduzia a questão através das relações editoriais com o "público" (HUGHES, 1945, p. 177); Darnton, ao contrário, disse que os repórteres não escrevem para uma "massa" disforme. Em um contexto hierárquico, eles trabalham para, em primeiro lugar, agradar seus editores (que definem as matérias que saem e os repórteres que as redigem), seus pares (que o legitimam) e, só depois, para algum público particular, e isso apenas no caso de uma especialização profissional.

Sobre a redação propriamente dita, o historiador chamou a atenção para dois pontos. Primeiro, falou da extensiva utilização dos manuais de estilo, nos quais são fixados os critérios de escrita, as regras mais gerais da profissão. Depois, lançou sua hipótese de trabalho, a qual apregoa a influência de antigas formas de contar "histórias" na moderna concepção noticiosa, a qual o levou a dizer que "as matérias jornalísticas precisam caber em concepções culturais prévias relacionadas com a notíciaß".

Se, por um lado, a academia brasileira de história deve muito, desde sua fundação, aos hommes de lettres franceses, o jornalismo, por outro, é calcado sobre uma tradição anglo-saxã mais acentuada. A introdução dos manuais de estilo significou um avanço rumo à padronização da linguagem e dos métodos de reportagem e redação. O processo pode ser entendido como parte do que já foi chamado de transição entre "regimes jornalísticos", entre a era de sua prática político-literária, publicista, e a de uma atividade reconhecida dentro dos moldes informativos de base empresarial moderna (RÜDIGER, 2003).

Não é sem razão que os chamados "critérios de noticiabilidade" formem um misto de ineditismo e atualidade (FOLHA DE SÃO PAULO, 2001, p. 22 e 43). A própria raiz da palavra latina "notícia" indica a novidade. E como seria então o desafio de se pensar o ontem enquanto reportagem, essa colonial history as news? Numa narrativa da história, se seguirmos as indicações da prática jornalística, a tarefa não deveria ser menos complexa e patentemente contraditória: seria preciso buscar alguma sorte de novidade e atualidade no tempo pretérito ${ }^{4}$.

3 Ou seja, “tudo que couber [nessas concepções culturais], a gente publica”. DARNTON, 1990, p. 96.

${ }^{4}$ Não que os critérios acadêmicos ignorem o ineditismo ou a novidade. De fato, são inúmeras vezes 
Notícia no passado? Desafio interessante pensar a obra de Eduardo Bueno dessa maneira, como uma "reportagem histórica", cheia de novidades em meio à tradição. No entanto, devemos levar em consideração as limitações do repórter - o qual não se apoia na erudição dos arquivos, nem no poder simbólico de um diploma - em selecionar os eventos de sua narrativa. Se pensarmos o jornalista como gatekeeper, temos de perceber que ele deve sempre referenciar as autoridades historiográficas. Neste caso, o porteiro dos fatos nada pode fazer sem prestar contas aos zeladores do passado.

\section{Autorizar a representação e representar a autoridade}

Ainda no primeiro livro da coleção Terra Brasilis, ao descrever os perigos que os navegantes lusitanos enfrentavam ao percorrer o Mar Tenebroso, isto é, o Oceano Atlântico, Eduardo Bueno lança mão de um artifício jornalístico bastante comum: "Um historiador moderno, o brasileiro Paulo Miceli, já fez a comparação: 'Muitos daqueles viajantes enfrentaram os mares como alguém que, hoje, entrasse num avião sem garantia do aeroporto no final da viagem"” (BUENO, 1998a, p. 30).

A afirmação do professor da Unicamp é uma paráfrase muito conhecida pelos professores de escola. Alguns livros didáticos lançados no calor dos 500 anos, inclusive, falariam da relação entre as grandes navegações e a conquista espacial (GUILLEN, 2000, p. 16). Esse é, sem dúvida, um comentário didático que visa a compreensão de um cenário passado através de uma analogia que o identifique com o presente. Mesmo em uma asserção como essa, tão casual, e que decerto não depende e nem faz justiça à qualificação do historiador, o jornalista parece se abster de responsabilidade. É como se ele dispusesse um microfone à frente do acadêmico, esperando certa declaração autorizada, ou, quem sabe, simplesmente checando uma hipótese de trabalho, credenciando um lugar comum.

essenciais para a aceitação de um trabalho. No entanto, defendo a ideia de que o considerado "novidade" no jornalismo é distinto do considerado "novidade" na academia, muito mais preocupada no "desenvolvimento do discurso histórico" do que na simples "atração de leitores", como propõe LEMANN, 1995, p. 790. 
Esse tipo de postura rendeu críticas severas, dentre as quais figuram acusações de certa superficialidade de seus textos. É comum ouvirmos que Bueno não vai às fontes (o que não é de todo verdade), que seus textos são apenas uma compilação de diversos estudos sobre a história colonial, uma obra de síntese desprovida de conteúdo próprio ou original. Recorrente também é o exprobro que qualifica seus livros como simplificadores e reducionistas. Contra todas essas acusações, o jornalista defende-se:

Eu escrevi um livro que, realmente, é repleto de simplificações e de generalizações correndo o risco consciente de fazer essas generalizações para atingir um número maior de pessoas. Porque é o seguinte: eu acho que falta generosidade, além de uma certa competência de estilo, à produção acadêmica do Brasil. As limitações de estilo existem, mas acho que elas não prejudicam tanto quanto uma certa arrogância na postura de alguns historiadores. De alguns, porque a produção historiográfica brasileira é de primeira grandeza, eu devo muito a ela. A minha obra é uma obra de segunda mão, sim. É uma obra de divulgação, sim. Não sou historiador, sou jornalista. (BUENO, 2000, grifos meus)

Eduardo Bueno justifica seus livros a partir do estatuto de uma "obra de divulgação" produzida por um jornalista. Repete o pensamento de seu colega Nicholas Lemann (1995), o qual afirmava que os "não-acadêmicos" teriam como preocupação fundamental atrair novos leitores. "Obra de segunda mão", ela é concebida como uma narrativa, composta por um escritor que reivindica o título de jornalista e que apela, quando julga necessário, às autoridades, os historiadores. Por um instante parece dizer, como os sábios da história eclesiástica descrita por François Hartog, "não sou auctor, mas o autor de minha compilação" (HARTOG, 2001, p. 33). Bem diferente das testemunhas de Charles Péguy, que no século XIX acreditavam se assemelhar aos historiadores, a inversão promovida pelo jornalista é no mínimo curiosa: o historiador é agora transformado em testemunha, reencontrando-se como autoridade livresca, erudita, não de ter visto ou ouvido, mas estudado 5 . Ela é chamada à ordem, como no caso de Paulo Miceli, muito mais por sua especialização e seus títulos do que pela originalidade do argumento. Compilador, Bueno joga com os autores que consulta, dispõe suas teses, de quando em

\footnotetext{
5 "Charles Péguy, que lamentava isso, observava", cita Hartog, "Você encontra um homem. Ele não passa de uma testemunha. Você vai encontrá-lo velho. Instantaneamente, ele não passa de um historiador" (...) "ele fala como um livro". PEGUY. Ch. Clio. Oeuvres en prose complètes. Bibliotèque de La Pléiade. Paris: Gallimard. 1992. T.III. p. 1.187-1.188. Apud HARTOG, 2001, p. 12.
} 
vez endossa uma, critica sutilmente a outra, sempre apoiado numa terceira, em um processo que tem como resultado certo estilo argumentativo próximo do jornalismo diário. "Como notou o historiador" (BUENO, 1998a, p. 38), "escreveu” (BUENO, 1998b, p. 102), “concluiu” (BUENO, 1999a, p 48), “diagnosticada pelo historiador” (BUENO, 2006, p. 134), "um dos principais pesquisadores do tema” (BUENO, 1999a, p. 33), são frases recorrentes na coleção Terra Brasilis.

Frente à autoridade do "eu estudei isso", o jornalista parece se calar. Sua função, como comunicador social, deveria ser tão somente a de mediar o conhecimento acadêmico às grandes audiências, "traduzir" dados e comentários produzidos pela “historiografia brasileira", que "é de primeira grandeza”, a qual Bueno reconhece inúmeros débitos (BUENO, 2000). Esse fenômeno literário já foi descrito como uma “ambição de invisibilidade" - tratar-se-ia de um mecanismo de ocultamento do narrador, e, se pensado assim por nós, agora aplicado a um texto sobre história (ESPERANÇA, 2006, p. 245). Como explica a jornalista Janet Malcolm, da revista The New Yorker:

O “eu” jornalístico é um narrador de toda a confiança, um funcionário ao qual foram confiadas as tarefas cruciais da narração, do roteiro e do tom, uma criação ad hoc, como o coro de uma tragédia grega. Ele é uma figura emblemática, uma encarnação da ideia do observador imparcial da vida. (MALCOLM, 1990, p. 159)

Essa estratégia tem alguns efeitos fundamentais. Os acadêmicos aparecem como fiadores das ações no texto. Mas até que ponto as autoridades historiográficas terão suas falas passivamente reproduzidas? Ou, invertendo a questão, até que ponto a narrativa jornalística vai se apropriar das assertivas historiográficas, ressignificando-as a partir de um lugar exógeno de produção?

O objetivo do repórter é tentar "extrair a verdade" dos testemunhos, sem refletir exatamente sobre o que seria essa verdade, já a encaixando dentro de fórmulas de exposição (CHIPPA, 1998, p.16), ou, como prefere Darnton, a “concepções culturais prévias relacionadas com a notícia”. Por aí, parte a representação jornalística do passado, regida por suas próprias lógicas de assimilação dos testemunhos e de relação com o tempo presente. 


\section{Da Aventura à Tragédia}

Como todo escritor que se preze, Bueno quer vender sua história. Ele sabe que não apenas deve escrevê-la de forma atrativa, como também embasá-la de maneira convincente. Para isso, utiliza diversos artifícios. Um deles é certamente a intervenção em espaços de polêmica. Comecemos, então, com alguns exemplos nos quais as autoridades historiográficas, como se estivessem em um franco debate, são mediadas através da participação do jornalista.

Ao introduzir a personagem de D. João III, Bueno não pôde deixar de explorar as controvérsias em torno de seu governo, de sua personalidade, de sua memória. "O julgamento que os historiadores fazem" dele, destaca, "varia de rasgados elogios às críticas mais mordazes" (BUENO, 2006, p. 44). Joaquim Romero Magalhães, apresentado como um dos "analistas portugueses mais respeitados da atualidade" (Idem, Ibidem), aparece apenas para caracterizar o filho de D. Manuel como uma pessoa de parcas capacidades intelectuais. Magalhães é um historiador contemporâneo que foi Comissáriogeral da Comissão Nacional para as Comemorações dos Descobrimentos Portugueses. Da maneira como descreveu D. João III, o rei não se "mostrou na infância e adolescência especialmente brilhante, apesar dos bons mestres que o educaram" (MAGALHÃES, 1997, p. 449).

A seguir, Charles De Witte entra em cena para dizer que o monarca lusitano pecava pela indecisão e pela morosidade política nas resoluções. E então, quando tudo parecia indicar a construção de uma personagem desassisada, João José Alves Dias é invocado. O professor da Universidade Nova de Lisboa é bem mais simpático ao personagem. Ele não tarda por alegar que a suposta lentidão de D. João III, em seus despachos burocráticos e diplomáticos, fazia parte de uma talentosa estratégia política, um instrumento prudente e habilidoso na manutenção da delicada neutralidade portuguesa diante da Espanha, do imperador Carlos V e, da França, do rei Francisco I. "O monarca era a figura chave", escreveu Alves Dias. "Ao contrário do que se tem dito e 
A maneira como os argumentos historiográficos são arranjados parece bastante ordenada: primeiro, apresentam o monarca como lento, parvo e taciturno, apenas preparando o terreno para uma grande explicação integradora: era demorado, aparentava inépcia, todavia, na verdade, jogava com isso a seu favor. Não é preciso negar os "fatos", nem sequer conciliá-los em um contexto, mas apenas rever os comentários que the foram feitos. Assim, Eduardo Bueno também joga, ele mesmo, com as adversidades, transformando uma controvérsia historiográfica em um recurso operador de verossimilhança. Vejamos outro exemplo.

Quando o frei franciscano Antônio Jaboatão descreveu a cena do desembarque do primeiro governador-geral no Brasil, o fez de uma forma pomposa, na qual Tomé de Souza aportava na praia ao som de tambores, guiado por uma grande procissão, desfilando glorioso para o espanto dos nativos. Essa descrição "apesar de improvável”, disserta Bueno, "vem sendo repetida ao longo dos séculos por vários historiadores" (BUENO, 2006, p. 89). Culpa de uma "aura um tanto fantasiosa" a qual, em realidade, “não encontra base no registro documental” (BUENO, Ibidem, Ibidem).

De fato, frei Antônio Jaboatão escrevera em 1758, mais de duzentos anos depois do ocorrido. Bueno, naturalmente, tem essa informação. E, como seu interesse não é a representação jaboatina do evento, alia-se a outro de seus personagens para se aproximar do real: o historiador baiano Edison Carneiro. A frota lusitana, segundo ele, desembarcava em território possivelmente hostil e uma chegada faustosa poderia facilmente transformar a empresa em tragédia. "A verdade é que simples considerações de estratégia militar devem ter impedido tamanho despropósito” (BUENO, 2006, p. 90),

\footnotetext{
${ }^{6}$ BUENO, 2006. p. 44-45. DIAS. João José Alves (Cord). Portugal: do Renascimento à Crise Dinástica. In: SERRÃO, Joel; MARQUES de Oliveira A.H. (Dir). Nova História de Portugal Presença, Lisboa. 1998. P. 725. "Na realidade", segue o historiador, "o protelamento das tomadas de decisão nada tinha a ver com irresolução, humor taciturno ou sensibilidade às opiniões dos que estavam próximos, mas sim com prudência e habilidade política”. Como se faz perceber, Alves Dias racionaliza a personagem, vista como um chefe de Estado moderno.
} 
afirma o jornalista com base nos trabalhos do autor de A Cidade de Salvador, repetindoIhe uma frase absolutamente idêntica, sem, no entanto, grafar aspas às palavras ${ }^{7}$

A tentativa de pintar um quadro verossímil apoia-se na autoridade historiográfica, aqui somada também a certa impressão de ineditismo frente ao que "vem sendo repetido" por “vários historiadores”, mesmo que ele não cite quais esses são. Não seriam eles os mesmos cronistas e comentadores que Edison Carneiro, na década de 50 do século passado, insinuava combater? A crítica à pátina dos livros escolares e à linguagem bacharelesca dos textos acadêmicos são recorrentes como elementos retóricos na Terra Brasilis. Seria justo apresentar aos seus leitores uma crítica a textos com mais de meio século de idade, como se seu vocabulário fosse representativo da historiografia contemporânea?

Mas o melhor exemplo da mediação e renegociação das falas historiográficas aparece um pouco mais tarde na obra de Eduardo Bueno, embora, da maneira como pretendo mostrá-la, essa atuação apresente-se como uma construção interpretativa do autor da compilação. Sua narrativa, "que mescla minúcias do Brasil colonial com um delicioso clima aventuresco", como celebrou a crítica apaixonada, segue esse tom ao relatar os primeiros anos da empresa imperial lusitana na América (CORTES, 1999). A Viagem do Descobrimento, Náufragos e Degredados e mesmo Capitães do Brasil são textos repletos de "muita aventura e personagens intrigantes", de acordo com a descrição de seu próprio escritor (Ibidem, Ibidem).

Um dos heróis do primeiro volume, D. Henrique, o Navegador, "de fato, se tornaria o patrono de uma aventura metódica e científica de caráter 'moderno'”. Filho de uma escola que não existiu, marujo que raramente cruzou o mar, o Infante olhava para os oceanos e não via "barreiras intransponíveis", mas uma "ampla rota comercial ao redor do planeta”. Pouco molhou os pés, como Bueno explica numa de suas retrancas laterais, mas deflagrou uma "saga" intelectual, uma "aventura da mente" (BUENO, 1998a, p. 51).

É essa aventura mental que vai caracterizar boa parte dos personagens presentes nos três primeiros livros da Coleção Terra Brasilis. Os entrelopos franceses, por exemplo,

\footnotetext{
${ }^{7}$ Conferir: CARNEIRO, Edison. A Cidade de Salvador: uma reconstituição histórica. Edição da organização Simões. Rio de Janeiro, 1954. p. 26.
} 
introduzidos já no segundo livro, "não há dúvidas”, tinham um cotidiano ainda mais “aventuresco do que o dos feitores lusos". "Talvez a própria aura de ilegalidade que cercava a operação" dos contrabandistas - "ligada exclusivamente à iniciativa privada" “concedesse aos franceses um grau de liberdade muito maior” (BUENO, 1998b, p. 75).

Mesmos as expedições guarda-costas que contra a atividade desses entrelopos se voltavam, precisavam contar, dentre suas fileiras, com "aventureiros" de toda a sorte. Muitos deles embarcavam "por contra própria, sem receber soldo", como escreve Bueno, parafraseando Jaime Cortesão (1954, apud BUENO, 1998a, p. 34). Após o estabelecimento das capitanias hereditárias, começam a se mesclar "duas visões de vida que, embora divergentes, sempre haviam caminhado juntas na história de Portugal, e que tinham ajudado a forjar a alma da nação". O escritor chega a essa ideia a partir da leitura de Gilberto Freyre, o qual opõe capitães e colonos, com sua vida sedentária e dada à agricultura, ao "espírito de aventura e gênio prático" dos degredados e traficantes de pau-brasil (BUENO, 1999a, p. 175-176) (FREYRE, 1971).

Aos poucos, ao somar páginas e páginas de leitura da obra de Eduardo Bueno, ao avançar seu ano de publicação da orla do comemorativo 2000 para a esfera de influência do fatídico 2006, a aventura vai deixando as ações e mentes de seus personagens quinhentistas. Logo, a expansão romântica deve ceder seu lugar ao projeto colonial. O tom de saga ganha contornos de tragédia. Tragédia que já será predominante em $A$ Coroa, A Cruz e a Espada, último livro publicado pela coleção. Nele o próprio termo aventura começa a ser obliterado por vocábulos mais trágicos. E não são apenas os inúmeros desastres naturais, afundamentos de naus e caravelas ou ataques de nativos que compõem esse quadro sombrio que nos é descrito. De forma pela primeira vez decisiva, circunstâncias e sujeitos mais abstratos entram em jogo na narração de Bueno.

“Uma profunda transformação político-administrativa desenrolava-se na península ibérica”, conta-nos Eduardo Bueno. O Estado lusitano começava, "a partir de 1540", a edificar uma série de mecanismos capazes de lhe aumentar o poder de "cobrar e controlar, vigiar e punir". Os numeramentos, o alistamento militar obrigatório, o estabelecimento de fronteiras mais bem traçadas, a instituição de um sistema judicial mais "poderoso e intrusivo" associado a taxações mais amplas e a formas de cobrança 
mais efetivas - esses são os sintomas, listados por Bueno, daquilo que "os historiadores chamam de consolidação do Estado moderno" (BUENO, 2006, p. 33), os historiadores, no caso, sendo Joaquim Romero Magalhães, de No Alvorecer da Modernidade, e João José Alves Dias, em do Renascimento à Crise Dinástica. Esse "novo regime” por eles descrito era “inteiramente incompatível com a ampla liberdade de ação e autonomia” concedidas antes aos donatários do Brasil (BUENO, Idem, Ibidem).

Um segundo fenômeno também viria a ocorrer no período. Igualmente, ele seria, para Eduardo Bueno, fundamental na mudança dos rumos de sua narrativa histórica, para o fim da aventura mental e física de seus personagens. A Espanha, assim como Portugal, viveria um "período de fechamento político e ideológico" (BUENO, 2006, p. 35). Uma tendência conservadora, reação contra o perigo protestante, encabeçada pelo “crescente poder concedido à Companhia de Jesus e o fortalecimento da Inquisição”. Igualmente, a data de 1540 é lembrada como o momento a partir do qual os jesuítas se transformariam no "novo modelo ideológico" presente nos "destinos de Portugal" (BUENO, 2006, p. 36). Em breve eles “condicionariam não apenas os horizontes religiosos, mas as perspectivas intelectuais da América portuguesa". Esse fenômeno, afirma, seria aquilo que "alguns historiadores portugueses" denominaram de grande viragem. Trata-se do arvorar da Contrarreforma na península Ibérica: "esse 'movimento rumo à rigidez e à codificação', e a deliberada 'exclusão de alternativas', decretaria o fim daquilo que, com alguma liberdade, se pode chamar de 'período romântico' do expansionismo luso", diz Eduardo Bueno, a partir da leitura do historiador norteamericano Harold B. Johnson, de O Império Luso-brasileiro (BUENO, Idem, Ibidem).

Mas a proposta de periodização dos primeiros anos da história colonial brasileira entre um período romântico, marcado pela aventura, e um outro período, diríamos, "trágico", marcado pela exclusão das alternativas, tolhimento da liberdade de ação dos personagens e frustração de suas expectativas, parece ser de autoria e responsabilidade do jornalista. Esse novo período coincide com o estabelecimento dos governos gerais na colônia lusitana. Não era mais possível manter o elevado grau de autonomia e liberdade de jurisdição que desfrutavam os capitães dos primeiros anos da experiência colonial. Antes livres das visitas dos corregedores, agora os "aventureiros" deveriam Ihes prestar 
contas. Com a "instauração do Governo-Geral e a criação do cargo de ouvidor-geral", escreve Harold Johnson, uma das principais referências de Eduardo Bueno no assunto, “acabou a autonomia da justiça local, instaurando-se o controle pela justiça do rei nas terras dos donatários" (JOHNSON, 1998, p. 364).

O jornalista, escrevendo um texto não ficcional - portanto sem a mesma liberdade para controlar as ações e o enredo que um romancista teria - consegue, pela seleção ordenada das fontes, sua profundidade e detalhe, construir uma ênfase que caracteriza o clímax da obra, o ponto de tensão máximo do drama histórico que encena:

No instante em que a caravela comandada por Gramatão Teles entrava com as velas desfraldadas na baía de Todos os Santos, na terceira semana de janeiro de 1549, ela não estava vindo apenas para anunciar o desembarque do primeiro governador-geral - marcado para dali a dois meses. Chegava também para estabelecer o início de uma nova era na história do Brasil. (BUENO, 2006, p. 37)

Embora sua bibliografia disponibilize subsídios que possibilitam esse tipo de enfoque, uma interpretação dessa natureza não se fará sem carregar consigo alguns esquecimentos. O próprio Harold Johnson, figurante tão presente nas afirmações de Bueno, chegou a dizer que "a criação de um governador régio na Baía pouco contribuiu para alterar a estrutura da colónia. De facto, ele limitou-se a vestir a pele de um capitão donatário mal sucedido" (JOHNSON, 1998, p. 235). O que convém notarmos nesse procedimento de seleção e descarte é, outrossim, uma noção de história assinalada pela crueza do presente, a qual se transporta 500 anos no tempo. O fato é que as restrições realizadas pelo novo aparelho estatal a um modus operandi antes baseado na liberdade de escolhas, nas elevadas expectativas de seus atores e na "iniciativa privada", terá consequências, na escrita de Eduardo Bueno, bem mais visíveis do que o triste fim de um período de incertezas e aventuras.

\section{Um novo gancho: o mensalão}

Em outra ocasião, tive a oportunidade de refletir sobre a relação entre a comemoração dos 500 anos do Brasil e a emergência da figura do jornalista-historiador 
(BONALDO, 2014, p. 255-277). Agora, para que possamos perceber a conexão entre as peripécias que transformam a aventura do descobrimento em tragédia da colonização, convido o leitor a afastar por um instante este texto. No site youtube.com, ao digitar o nome "Eduardo Bueno", seguido de "A coroa, a Cruz e a Espada", encontra-se com facilidade o vídeo promocional da obra, criado pela editora Objetiva ainda no ano de lançamento do livro, 2006.

Uma música tanto intensa, certo ar épico, acompanhada de fundo azulado por inscrições cartográficas: “Ministro da justiça desviou verbas públicas (Salvador, 1546)”, “Empreiteiros acusados de superfaturamento na Bahia (Salvador, 1551)" e "Alguma semelhança com os dias de hoje?". São essas frases que flutuam no vídeo, como que convidando o espectador a agarrá-las, consumi-las de modo a "entender as origens de um Brasil corrupto e burocrata"8. Usos e abusos de uma "história mestra da vida", talvez? Um novo gancho, com certeza: olhos no tempo presente - o 2006 dos "escândalos do mensalão" - termina por transportar o significado contemporâneo da palavra corrupção cerca de 500 anos no passado.

Mas o que dizem as fontes de Bueno? Onde ele sugere ver as origens do nepotismo na administração pública, Edison Carneiro pontua o elevado número de escrivães presentes na colônia, "sem dúvida desproporcionais para as coisas do govêrno geral” (CARNEIRO, 1954, p. 33). Duas páginas depois, complementa a informação ao dizer que não eram eles os responsáveis pelos "desvios que houvesse, e sim o almoxarife e, depois dêle, o contador; que os irmãos e os criados do almoxarife tinham as chaves dos armazens e davam e tiravam tudo o que queriam". Também afirmava que "com êsse novo processo, tentava-se fazer pagar à custa da Fazenda Real e da sua honra pessoal, os 'passatempos' do almoxarife de parceria com o filho do governador, Àlvaro da Costa” (CARNEIRO, 1954, p. 35).

Apesar de indicar a ocorrência de "desvios", o que é repetido nas páginas de $A$ Coroa, A Cruz e a Espada, a seleção desses fatos dispõe uma ênfase originalmente inexistente na questão da "corrupção" (BUENO, 2006, p. 35). Logo a seguir, Edison

\footnotetext{
${ }^{8}$ Ainda disponível em: <http://www.youtube.com/watch?v=CSICWiBDQ6A>. Acesso em 20/10/2016.
} 
Carneiro relata as sugestões de Tomé de Souza, no sentido de diminuir o número de empregados da Coroa. "Em carta pessoal ao rei", o governador dizia que "Ihe parecia conveniente não nomear Provedor-Mór da Fazenda, pois o Ouvidor Geral poderia acumular o cargo, com o auxílio de dois escrivães, um da justiça, outro da fazenda". Essas propostas teriam sido bem recebidas pelo monarca (CARNEIRO, 1954, p. 37).

Teodoro Sampaio, estudioso das origens de Salvador, é também muito referenciado por Bueno. Em seu estudo clássico, História da Fundação da Cidade de Salvador, o historiador baiano disserta sobre os vícios que se praticavam na nova colônia. Para tanto utiliza, sobretudo, os relatos do Padre Nóbrega, a quem:

Impressionam sobremaneira a sua visão perfeita dos negocios publicos, os remedios que lhe acudiam, a solução habil que lembrava aos problemas do governo, como se fora consumado politico e administrador. Para elle não podia haver prosperidade onde a justiça e a moralidade não reinavam. (SAMPAIO, 1949, p. 236)

Justiça e moralidade: esse seria o tom das críticas feitas pelo enviado da Companhia de Jesus à terra do Brasil. Teodoro Sampaio, como historiador erudito que era, ao longo de seu texto tende a emular as fontes, incorporar seus significados, chegando mesmo a - como mostra palavra supracitada - identificar-se positivamente com alguns personagens. Padre Nóbrega, para ele, é um herói civilizador. Sabia submeter os índios pela força como também maldizer os abusos dos cristãos (SAMPAIO, 1949, p, 236). No entanto, o tom de condenação moral que existe em Nóbrega e é transposto para História da Fundação ganha contornos marginais na obra de Eduardo Bueno. Para o jornalista gaúcho, "Teodoro Sampaio”, dentre outras descrições de práticas corruptas, "analisa o superfaturamento das obras contratadas sobre o regime de empreitada" (BUENO, 2006, p. 265).

Mais importante do que entender o passado em seus termos seria buscar nele lições que sirvam para o tempo presente? Uma evidência desse antigo topos seria o relato que Bueno faz da construção dos primeiros muros que cercaram Salvador: 
Antes do fim do ano de 1550 , os muros e seus respectivos baluartes estavam prontos, e as muralhas erguidas com tanta rapidez não parecem ter recebido a devida atenção. Cerca de seis meses mais tarde, no início do segundo semestre de 1551, parte delas desabou após uma chuvarada. (SAMPAIO, 1949, p. 236)

É novamente a Teodoro Sampaio (citando carta do construtor Luiz Dias à Dom João III e Roteiro do Brasil de 1587) que o autor de A Coroa, a Cruz e a Espada deveu essas informações 9 . "Em verdade", lê-se na História da Fundação, "a julgar pelo que elles duraram, bem pouco valia a sua fortaleza" (SAMPAIO, 1949, p. 193). Mais adiante no texto de 1949, observa-se ainda uma curiosa leitura sobre a ruína das muralhas:

A cidade havia já transbordado do seu recinto primitivo. As suas portas sob o Castello já se não fechavam e os seus muros derruídos pareciam dizer que o seu tempo, aquelle do gentio bravo e ameaçador, era passado. (SAMPAIO, 1949, p. 225)

Anos depois, "a cidade, ao tempo de Luiz de Britto e Almeida, já não tinha muros". Ela "crescera a exceder de muito o âmbito da primitiva cerca" (SAMPAIO, 1949, p. 273). Para o historiador baiano, as técnicas europeias empregadas por Luís Dias na fortificação da cidadela eram claramente impróprias. "Sob a acção deletéria deste clima tórrido", anotou, "as mais solidas construções rápido se desconjuctam e desmancham" (SAMPAIO, 1949, p. 254). Em suma, quando Teodoro Sampaio vê trabalho inadequado e expansão da área urbana, Eduardo Bueno ressalta indícios de corrupção e superfaturamento $^{10}$. O foco da narrativa, por mais que esteja ainda referenciada em Sampaio (e que ele indique as "infrações costumeiras" dos colonos), modifica-se profundamente ${ }^{11}$. Vejamos o que Eduardo Bueno nos diria mais tarde, falando não apenas

\footnotetext{
9 SAMPAIO. op. cit. p. 193. Citando: Carta a El-Rei D. João III de 15 de Agosto de 1551 e Roteiro do Brasil de 1587 - Cap V - p. 115.

${ }^{10} \mathrm{Na}$ verdade, durante toda a história da Fundação da Cidade de Salvador, Teodoro Sampaio parece indicar como elemento fundamental de sua narrativa o trabalho de adaptação do europeu aos trópicos. Chega mesmo a dizer, após longo e típico preâmbulo sobre a geografia e condições climáticas da Bahia, que "a Terra era, na verdade, ainda muito verde para se adaptar aos rigores de uma legislação, transplantada e evoluida em meio diverso". SAMPAIO. op .cit. p. 210.

11 "Os infractores eram costumazes e as penas não passavam de ameaças. Os atravessadores de mercadorias zombavam das medidas, que contra seu commercio aladroado adoptavam os Officiais da Camara. Os arrendatários dos impostos conluiavam-se contra os mercadores, consentindo que estes fraudassem as almotaçarias" SAMPAIO. op. cit. 211. O contexto dessa citação é, justamente, o de uma terra ainda pouco preparada - ou civilizada - para as legislações europeias.
} 
sobre a questão específica dos muros, mas acerca de todo o problema da corrupção e dos desvios de verbas ocorridos nos primeiros anos da cidade de Salvador:

Nesse ponto é claro que eu puxei para o presente. Claro que eu fiz a "autópsia", mais uma vez. (...) Claro que eu tentei fazer com que o leitor traçasse um paralelo entre aquela corrupção e a de hoje. (...) É claro que a metáfora ali é Brasília. E claro que a metáfora - e que isso fique registrado - é a Odebrecht, a OAS e a Gautama, que são inclusive baianas. É deles que estou falando.'2 (BONALDO, 2011, p. 139)

\section{Uma implicação ideológica no conteúdo da forma?}

\section{"o sentimento de aventura será, tão simplesmente, aquele da irreversibilidade do tempo"}

(SARTRE, A Náusea) ${ }^{13}$

Eduardo Bueno, autor de uma compilação, não deixa de oferecer uma interpretação do Brasil. O Estado brasileiro, em sua origem, estava envelhecido. O fardo do presente cravou-lhe a experiência, assentando-lhe a identidade provecta pelo signo, talvez anacrônico, da corrupção. Mas a questão aqui não é a verdade sobre o passado se houve ou não "corrupção" na Salvador quinhentista, deveria parecer ao menos verossímil a qualquer pessoa sensata ${ }^{14}$. O que interessa é compreender o movimento que transporta as palavras “corrupção" e "superfaturamento" (termos escassamente utilizados pelos historiadores aludidos na compilação Terra Brasilis, mas vulgarizados ad nauseam por seu autor) tantos séculos na história.

\footnotetext{
${ }^{12}$ BUENO, Eduardo. Entrevista para o autor. Março de 2010.

13 "Le sentiment de l'aventure serait, tout simplement, celui de l'irreversibilité du temps" SARTRE, J. P. La Nausée. Paris: Gallimard, 1938. P. 85. Tradução minha.

${ }^{14} \mathrm{O}$ problema, em si, talvez seja menos interessante do que se perguntar, afinal, o que significa ser "corrupto" dentro do contexto de um Primitivo Estado Moderno, em pleno século XVI? Mesmo Edison Carneiro e Teodoro Sampaio, escrevendo na primeira metade do século XX, quando dissertam sobre o assunto, o fazem no contexto de uma condenação moral - sentido, aliás, emulado das fontes, em especial de Padre Nóbrega. Será que, para entender o problema, não deveríamos estudar os pecados capitais, a moral católica contra-reformada, o jusnaturalismo posterior que a secularizou e permitiu, enfim, o emprego anacrônico do termo "corrupção" ao século XVI?
} 
O lusitanista Harold Johnson é mais incisivo e refinado em suas considerações acerca dessas práticas denunciadas por Eduardo Bueno. Raciocina sobre a "contaminação da esfera do público pela do privado", um problema para o qual "as medidas tomadas pela Coroa (...) nunca se revelaram suficientemente eficazes" (JOHNSON, 1998, p. 151). O escritor gaúcho, desprovido dessas mediações conceituais - possivelmente creditando a elas certo tom acadêmico que deve ser mediado por uma linguagem mais próxima do senso comum de seus leitores - relaciona a reflexão de Johnson diretamente à “corrupção e os desmandos que imperavam na capital” (BUENO, 2006, p. 248).

E quanto à viragem de que falam os historiadores portugueses? Ela parece mais próxima de uma expressão para a virada do século, XV para XVI, final da Idade Média e “alvorecer da modernidade" ${ }^{15}$. Inclui também a percepção do estabelecimento do Estado moderno, da contrarreforma católica, uma intensa consciência da descontinuidade em relação ao medievo - mas não há nessas constatações um juízo de princípio moral relacionado à emergência do primitivo Estado moderno (DIAS, 1998, p. 336). Essa asserção, no entanto, torna-se central para a estrutura narrativa de Eduardo Bueno. A "grande viragem historiográfica" torna-se o turning-point jornalístico.

Quando perfeitamente enquadrada dentro de um gancho, a narrativa jornalística têm como principal contribuição a capacidade de lançar uma questão a partir do presente e, em seguida, selecionar as fontes, delimitar suas passagens, circunscrever uma ênfase e observá-la em sua "origem" como se olhasse num espelho. O passado, tornado presente, carrega no ontem as marcas do hoje, seja pela rejeição aos instrumentos conceituais de mediação (vistos como pernosticidade ou mesmo arrogância acadêmica), seja pela ansiedade deliberada por uma temática "obviamente relevante" à sociedade atual.

O texto jornalístico, escrito em sintonia com os debates públicos, preocupações midiáticas e delegações políticas, flui ao sabor de seu tempo não apenas pelo "dinamismo da narrativa", mas pelo dinamismo das comemorações e suas demandas identitárias. Perfeitamente integrado numa "economia midiática do presente", termo que tomo de

\footnotetext{
15 "Se a viragem de meados do século XVI poderia ter concretizado uma outra opção para este volume, não se torna difícil justificar o que se tomou. O Portugal do limite a quo apresenta-se muito outro do limite ad quem. Houve profundas modificações em todos os aspectos." MAGALHÃES, Joaquim Romero (Cord), op. cit, p. 15.
} 
“superfaturamento" e “nepotismo" (BUENO, 2006, p. 139). Converte, dessa maneira, seus personagens em "homens de carne e osso" (BUENO, 1999b), muito mais próximos ao universo moral dos leitores modernos. O passado devidamente contemporaneizado retorna aos dias atuais através das laudas de uma narrativa jornalística da história. Quando, após horas absortas na leitura, fechamos por fim suas páginas, encerramos com elas um "círculo do presente" ${ }^{16}$.

Mas os significados propostos pela narrativa jornalística da história revelam uma intencionalidade autoral que, talvez, possa e deva ser analisada a partir de referentes mais concretos. Além de ver neles as origens da corrupção, do nepotismo e da burocracia no Brasil, Bueno interpreta o estabelecimento dos governos gerais como o "primeiro conflito entre o indivíduo e o Estado em terras brasileiras" (BUENO, 2006, p. 36). Um dos varões de A Coroa, a Cruz e a Espada é também um herói da iniciativa privada. Duarte Coelho, donatário de Pernambuco, não apenas foi bem sucedido em sua empresa colonizadora "após vender todas as suas posses no reino e arregimentar duas centenas de colonos". Ele chegou a combater "o desmatamento e a poluição provocada pelo despejo do bagaço de cana nos rios” (BUENO, 2006, p. 145). A inclusão de um sentido mais ou menos velado dentro da narrativa histórica pode parecer evidente, mas ao que indica não é assumido:

O objetivo de meus livros não é ideológico, no sentido mais rasteiro da palavra. Mas sim que os leitores cheguem as suas próprias conclusões. Só pretendo fornecer dados e informações. Tenho uma certa obsessão pela minúcia de detalhes que permita aos leitores interpretar a história por si. Acredito que seja uma postura muito mais libertária. (BUENO, 2000)

Talvez seus escritos não sejam ideológicos "no sentido mais rasteiro da palavra" (sic), se por isso entendermos a categoria como aquela presente nos trabalhos do jovem Marx, da inversão da realidade em uma câmera obscura (MARX;ENGELS, 2002). Mas, caso

\footnotetext{
${ }^{16}$ HARTOG. Idem. Utiliza essa expressão nas páginas 115 e 125.
} 
(WHITE, 1992, p. 36). Hayden White, como leitor de Althusser, entendia a escrita da história "primordialmente como uma forma de ideologia". Por isso, alega um de seus inúmeros críticos, o autor de Meta-História privilegiava o tropo da ironia, visto como um tipo imanente de crítica da narrativa histórica capaz de transcender os níveis mais baixos da disputa ideológica (CALLINICOS, 1995, p. 51-52). Porém, White (1992) não foi o único nome da teoria da história a agarrar-se ao desafio de reabilitar a instrumentalidade do velho conceito marxista.

Em Ideologia e Utopia, Paul Ricoeur (1997) propõe distinguir três níveis operatórios da ideologia, traçados de cima a baixo, do superficial ao mais profundo. Seus efeitos são sucessivamente o de distorção da realidade (encontrado no jovem Marx), de legitimação do sistema de poder (lido em Max Weber) e o de integração do mundo via sistemas simbólicos imanentes à ação (percebido nas etnografias de Clifford Geertz). É esse terceiro e último nível que metodologicamente pode nos ser eficaz. Acredito ser profícuo, a partir dele, observar as correlações que se estabelecem entre a representação das motivações humanas e os sistemas valorativos do presente. A ideologia, assim pensada, ganharia contornos mais precisos, tornando-se especificamente uma forma de instrumentalizar a memória incorporando-a dentro de um sistema simbólico, no caso, aquele de um ideário liberal? Os personagens do passado, seus cenários, suas ambições, por meio dela são subsumidos no círculo do presente que os narra através de uma "retórica dos tropos" ${ }^{17}$.

A própria atividade profissional jornalística, é verdade, pode ser vista como produto da sociedade burguesa liberal. Jürgen Habermas, em sua Mudança estrutural da esfera pública, dizia que o incremento do trânsito de mercadorias e de informações na modernidade não podem ser mecanicamente separados em processos de

\footnotetext{
${ }^{17}$ Ao comentar e atualizar suas conclusões em obra posterior, o filósofo diz a respeito desse terceiro estrato da ideologia que "uma correlação notável se estabelece nesse nível fundamental entre síntese simbólica e sistemas semióticos, alguns dos quais dependem francamente de uma retórica dos tropos". RICOEUR. 2007. p. 95.
} 
desenvolvimentos distintos. A própria informação tornou-se, em realidade, uma mercadoria (HABERMAS, 1984, p. 34-35). Mesmo que o crescimento da prática jornalística tenha sido alavancado por periódicos patrocinados muitas vezes pelos Estados nacionais, aos poucos sua lógica e seus discursos de legitimação passaram pela ideia da liberdade opinativa.

Como um produto à venda, o jornalismo, em tese, sujeitaria-se, dentro do espaço público, às mesmas regras do mercado livre. A síntese do processo de concorrência igualitária de informações seria a constituição daquilo que chamamos de opinião pública. O leitor, livre para escolher o texto que melhor convém as suas expectativas e visões de mundo, agiria como peça fundamental de uma mão invisível que seleciona as informações e enfoques mais capacitados para sobreviver em uma sociedade aberta.

Até que ponto esse ideário corresponde à realidade concreta não cabe aqui analisar. O que interessa é o fato de que, em certa medida, a memória disciplinar do jornalismo reivindica essas referências como parte de sua deontologia - no sentido bourdiano, o discurso que um campo realiza externa e internamente como forma de construir sua legitimidade, baseado em um código de conduta ético-profissional (BOURDIEU, 1996).

Sem prejuízo do chiste político, as características liberais das práticas midiáticas e jornalísticas já foram levadas em consideração inclusive pelos seus mais notórios defensores. Gilles Lipovetsky, em Metamorfoses da cultura liberal, acena para o papel que a mídia teve, ao longo do século XX, em dar “maior estabilidade à ordem democrática”, auxiliando com que "pela primeira vez, depois do fim do século XIX, as sociedades liberais não tenham outro projeto político" (LIPOVETSKY, 2004, p. 84-86).

A imprensa brasileira possuiu, como mostrou Maria Aparecida Aquino (1999), um importante papel na constituição da memória de resistência à ditadura iniciada em 1964. Como exemplo, o documentário Vlado: 30 anos depois (João Batista de Andrade, 2005) incutiu um novo significado à biografia do repórter Vladimir Herzog. Assassinado nos porões da ditadura militar em 1975, o militante comunista foi perfilado, através da seleção jornalística dos testemunhos, como se fosse um defensor da democracia liberal. 
A constituição de uma verdadeira "tradição jornalística liberal" foi comentada por Mateus Henrique de Faria Pereira em sua investigação acerca da escrita da história nas páginas do Almanaque Abril (PEREIRA, 2009, p. 65-66). Nesse contexto, Victor Civita, editor daquele grupo empresarial, afirmava em 1978 que "consideramos a livre iniciativa o único sistema compatível ao mesmo tempo com uma sociedade pluralista, com as liberdades fundamentais do indivíduo, com a eficiência, com o dinamismo, com a inovação" (CIVITA apud PEREIRA, 2009, p. 65).

Décadas mais tarde, Eduardo Bueno diria que "a solução do mundo passa pelos direitos do indivíduo". Para o jornalista e historiador não acadêmico, "em países onde as pessoas têm uma visão histórica e política mais completa, elas têm um exercício de sua ação individual mais completa também." De todo modo, sua posição existencial afirmavase categoricamente: "Eu só respeito o indivíduo. Por respeitar a mim eu respeito o indivíduo único, indivisível” (FERLA, 2010). Justificando seu sucesso, ele diria:

Eu acredito no mercado. Acredito numa economia de mercado. Acredito no poder da venda e do dinheiro e fiz esses livros para vender. Na melhor acepção da palavra vender. Vender no sentido de obter sucesso. Do mesmo modo que um cantor que grava um single, pensa ter uma mensagem a dar, como eu achei que tinha, só que além de ter essa mensagem ainda quer que ela venda e faça sucesso. Então eu lancei um produto. Isso mesmo: um produto. (BONALDO, 2011, p. 125)

A tradução de seu individualismo deixa clara sua posição política: "A popularidade do governo Lula vem de gente que desconhece a própria história, que desconhece a história como está acontecendo, que ganha bolsa família, o que, por um lado, revela que os outros eram ainda piores" (NOVAES, 2007). Quem sabe como resultado se veria em A Coroa, a Cruz e a Espada que "os males do Brasil são tão antigos quanto seus primeiros habitantes. Corrupção, burocracia, clientelismo (...)" enquanto que a "teia nepotista de um funcionalismo público leniente, omisso e preguiçoso - embora muitas vezes mal pago - está, por exemplo, nas origens de um sistema previdenciário desequilibrado e de uma carga tributária absurda"? Para completar a peça publicitária desse seu último livro, o jornalista encarnava seu lado Men with a Mission: “É gente demais, trabalhando de menos 
há tempo demais... Chega de tanto cabide de emprego" (apud BONALDO, 2010, p. 74). Ecos de Edison Carneiro? Ou seriam vozes de presença liberal?

Será possível que as demandas por um "Estado mínimo" (típicas no gancho das comemorações) tenham se associado à crítica do inchaço e da corrupção do bem público (que ganha força já em 2006) e integrado à narrativa de Eduardo Bueno em uma fórmula de explicação por implicação ideológica liberal? Propus reconhecer esse dado como um elemento que se expressa narrativamente através da articulação mediada das autoridades historiográficas. Mediadas por um lugar social e epistemológico de produção exógeno à academia, têm como traço autoral o estabelecimento de representações de continuidade operacionalizadas através do uso de paralelos: pôr "diante dos olhos" (ante oculos ponere), através de comparações materiais e morais, expediente antigo (cf. Retórica a Herênio, IV, 46) digerido ao longo da modernidade, que bebeu em seus exemplos com o sincero intuito de "arrancá-los dali e pô-los na vitrine" (MONTAIGNE, 2010, p. 101).

Se a "cientifização (...) colocaria o pensamento histórico em contradição com sua função de orientação da vida prática" (RÜSEN, 2001, p. 126), pintando descontinuidades no seio da tarefa de nortear a experiência humana no tempo, o lugar do jornalista - que deve pouco à memória disciplinar da historiografia, rejeitando a teoria como afetação acadêmica - pode encontrar uma antiga tópica. Não é a força da mos maiorum, a pulsão em reproduzir os exemplos ancestrais, que, no entanto, articula uma historia magistral vitae na coleção Terra Brasilis. Por um lado, temos a identificação do autor com o procedimento dos paralelos: desde a "iniciativa privada" (BUENO, 1998a, p. 28) das primeiras expedições, passando pelo relato quase "jornalístico" de Pero Vaz de Caminha (BUENO, 1998a, p. 114-116), aportando no "sumiço do dinheiro" (BUENO, 2006, p. 124) em tempos de colônia. Se “os fatos são sagrados, mas os comentários são livres", como reza um conhecido provérbio do jornalismo liberal inglês (MOREIRA, 2004, p. 275), o repórter que escreve sobre história está livre para identificar-se no passado. Chancelado, por outro lado, pelo prognóstico racional de ganhos materiais através da noção de "gancho", livre igualmente está para unir as regras de um lugar com um topos antigo. Tópica que reorienta-se na modernidade, de Edmund Burke a Georges Santayana, atribuída também 
O espaço das redações, ungido por laços de solidariedade editoriais, lembra uma tópica - um antigo lugar de memória - também sede de argumentos (YATES, 2006) agora atualizados pela proliferação comemorativa dos modernos lugares de memória descritos em seu caso francês por Pierre Nora (1992/1997, p. 4697 e passim). A própria solução para os muitos dos desmandos da corrupção é encontrada por Bueno nessa historia magistra que é como um "cadinho de experiências” (GUIMARÃES, 1998, passim; KOSELLECK, 2006, 47 e passim). Em nota lateral de A Coroa, a Cruz e a espada, Pero Fernandes Sardinha aparece recomendando a D. João III a aprender com o que Plutarco escrevera sobre as ações de Trajano e Antonino Pio: não deixar os governadores de províncias distantes arrebanhar mais terras do que já possuíam (BUENO, 2006, p. 139).

Como já disse seu autor, "a coleção [Terra Brasilis] era um produto fechado para o mercado" (BONALDO, 2011, p. 127). Como produto, sua estratégia literária carregava a intenção de, abolindo os mecanismos de mediação com o passado, transformar o leitor em "testemunha presencial" dos acontecimentos (Idem, p. 133). Com esse procedimento, a "cobiça" expressa nas fontes é transformada em "corrupção" no sentido contemporâneo, indicando uma pulsão, cremos, supra-histórica que possibilita um uso do passado legitimado pelas “concepções culturais prévias” presentes nos critérios de noticiabilidade.

\section{Considerações Finais}

Isenção, neutralidade ou espelho jornalístico do real: aprender a história em uma "Escola sem Partido" indicaria a necessidade de seu vigiar e punir, igualmente, os representantes do jornalismo liberal? Como autor de uma compilação, Eduardo Bueno não deixa de lembrar, assinalar e esquecer, compondo significados ideológicos capazes de serem desvelados pela análise do conteúdo da forma. Ainda uma vez temos a agonística do indivíduo e do Estado (SPENCER, 1912). Transformar o leitor em 
Nos países de língua anglo-saxã - mais acostumados ao debate sobre a relação do fazer histórico com a recepção das grandes audiências - tanto "popular history makers" quanto "professional historians" há tempos possuem uma formação de expertise universitária (MALERBA, 2014, p.:31). Por outro lado, no Brasil, ao menos se pudermos confiar nas listas de mais vendidos, este não parece ser o caso: os best-sellers de história ainda habitam em grande medida terreno de profissionais da comunicação social. Essa forma diferente de representar a história, talvez possua um elevado grau de êxito na composição de um sentido capaz de "estabilizar a identidade de seus destinatários ao longo das mudanças no tempo" (RÜSEN, 2001, p. 125). Mas essa narrativa jornalística da história (que preza os fatos como sagrados e toma os comentários como "livres") seria capaz de unir a certeza das ocorrências com a autoconsciência do sentido atribuído narrativamente a elas, critérios fundadores da moderna historiografia? ${ }^{18}$ Nesse caso, teríamos não a ciência da história, não o reconhecimento da distância que nos separa de um passado profundo, mas a lembrança exemplar, a atualização ou presentificação do "Brasil colônia" de acordo com critérios de nosso tempo. Afinal, a "simultaneidade do não-contemporâneo" tão bem impressa nas páginas da coleção Terra Brasilis não teria como resultado evidenciar as "falhas" de um presente incapaz, para dizer o mínimo, em compreender e transmitir a alteridade do passado?

\footnotetext{
${ }^{18}$ Lembro aqui da hipótese clássica para o surgimento da historiografia moderna, anunciada por Vico ("II vero alla prova del certo. Il certo alla prova del vero") e evidenciada por Momigliano com mais clareza em Winkelmann e Gibbon, representantes de uma geração que teria unido a reflexão à la Voltaire sobre o sentido da história (relacionada à verdade filosófica) com as contribuições críticas da pesquisa antiquária (interessada na certeza sobre as ocorrências), superando o pirronismo e esboçando os critérios da verdade histórica (MOMIGLIANO:2004:112). Deixamos de lado, entretanto, toda a discussão desenvolvida desde ao menos a segunda metade do século XX no âmbito do chamado "giro-linguístico", a qual fugiria ao escopo do presente artigo. Para um bom sumário do debate, ver a coletânea organizada por MALERBA:2016.
} 


\section{Referências}

AQUINO, Maria Aparecida. Censura, imprensa e estado autoritário: o exercício cotidiano da dominação e da resistência. Bauru: Edusc, 1999.

BONALDO, Rodrigo Bragio. A narrativa jornalística da história: o passado como produto para o mercado. História Oral (Rio de Janeiro), v. 14, p. 123-144, 2011.

BONALDO, Rodrigo Bragio. Um fardo do presente? O jornalista entre a história e a memória. In: MAGALHÃES, Marcelo; ROCHA, Helenice; RIBEIRO, Jayme Fernandes; CIAMBARELLA, Alessandra. (Orgs.). Ensino de história: usos do passado, memória e mídia. 1. ed. Rio de Janeiro: FGV, 2014, p. 255-277.

BOURDIEU, Pierre. Sobre a televisão. Rio de Janeiro: Jorge Zahar, 1996

BUENO, Eduardo. História do Brasil. Porto Alegre: Zero Hora/RBS Jornal. 1997.

BUENO, Eduardo. Brasil: uma História, a incrível saga de um país. São Paulo. Ática. 2003.

BUENO, Eduardo. A viagem do descobrimento: a verdadeira história da expedição de Cabral. Rio de Janeiro: Objetiva, 1998a

BUENO, Eduardo. Náufragos, traficantes e degredados: as primeiras expedições ao Brasil, 1500-1531. Rio de Janeiro: Objetiva, 1998b

BUENO, Eduardo. Capitães do Brasil: a saga dos primeiros colonizadores. Rio de Janeiro: Objetiva, 1999a

BUENO, Eduardo. Convite para a viagem do autodescobrimento: juntar-se à frota de Cabral faz bem ao espírito. Revista Época, n. 51, 10 de maio de 1999b.

BUENO, Eduardo. A coroa, a cruz e a espada: lei, ordem e corrupção no Brasil Colônia. Rio de Janeiro: Objetiva, 2006.

BUENO, Eduardo. Entrevista com Eduardo Bueno. EXTRA Classe. Abril de 2000. Disponível em: < http://www.sinpro-rs.org.br/extra/novoo/entrevista.asp >. Acesso em: 09/02/09.

BUENO, Eduardo. Povo que não conhece sua história está condenado a repeti-la [Blog]. 2012. Entrevista para o blog Minuto Palmeira dos índios. Disponível em: <http://minutopalmeiradosindios.com.br/noticia/648/2012/04/25/povo-que-nao-conhece-asua-historia-esta-condenado-a-repetila>. Acesso em: 10/11/2016. 2012. 
CALLINICOS, Alex. Theories and narratives: Reflections on the philosophy of history. Durham: Duke University Press, 1995.

CARNEIRO, Edison. A cidade de Salvador: uma reconstituição histórica. Rio de Janeiro: Organização Simões, 1954.

CERTEAU, Michel De. A escrita da história. 2. ed. Rio de Janeiro: Forense Universitária, 2000.

CHIPPA, Marcos (Org). Entrevista e ética: uma introdução. São Paulo: Edusc, 1998.

CORTESÃO, Jaime. Fundação de São Paulo: capital geográfica do Brasil. São Paulo. 1954.

CÔRTES, Celina. O Historiador pop. Entrevista com Eduardo Bueno. Revista Isto É. 24/2/1999.

DARNTON, Robert. O Beijo de Lamourette: mídia, cultura e revolução. São Paulo: Companhia das Letras, 1990.

DIAS. João José Alves (Cord). Portugal: do Renascimento à Crise Dinástica. In: SERRÃO, Joel; MARQUES de Oliveira A.H. (Dir). Nova História de Portugal. Lisboa: Presença, 1998

ESPERANÇA, Clarice Gontasrki. Testemunhas ou fontes: relações e desencontros entre jornalistas e historiadores. Em Questão, Porto Alegre, v. 12, n. 2, p.235-251, jun./dez., 2006.

FERLA, Marcelo. Peninha, vulgo Eduardo Bueno. In: Suburbia08: memorabilia, achismos \& devaneios [Blog.], 2010. Disponível em:

<http://suburbia08.blogspot.com/2008/05/peninha-vulgo-eduardo-bueno_04.html>. Acesso em 15/02/2010.

FOLHA DE SÃO PAULO. Manual da redação. São Paulo: PubliFolha, 2001.

FREYRE, Gilberto. Novo mundo nos trópicos. São Paulo: Companhia Editora Nacional, 1971.

GOMES, Laurentino. 1808: Como uma rainha louca, um príncipe medroso e uma corte corrupta enganaram Napoleão e mudaram a História de Portugal e do Brasil. São Paulo: Editora Planeta do Brasil, 2007.

GUMBRECHT, Hans Ulrich. Production of presence: what meaning cannot convey. Stanford: Stanford University Press, 2004. 
GUILLEN, Isabel. 500 Anos um novo mundo na TV. Brasília : MEC. Secretaria de Educação a Distância. 2000, p. 16. (Cadernos da TV Escola 1).

GUIMARÃES. Manoel Luiz Lima Salgado. Nação e civilização nos trópicos: O Instituto Histórico e Geográfico Brasileiro e o Projeto de uma História Nacional. Estudos Históricos, Rio de Janeiro. n. 1, 1988.

HABERMAS. Jüngen. Mudança estrutural da esfera pública. Rio de Janeiro: Tempo Brasileiro. 1984.

HARTOG, François. A testemunha e o historiador. In: PESAVENTO, Sandra Jatahy (Org). Fronteiras do milênio. Porto Alegre: Editora da UFRGS, 2001.

HARTOG, François. Regimes d'historicité: Présentisme et expérience du temps. Paris: Éditions du Seuil, 2003.

HUGHES, Helen MacGill. Newspapers and the Moral World.The Canadian Journal of Economics and Political Science: Revue canadienne d'Economique et de Science politique, n.11, n.2, maio, 1945.

JOHNSON, Harold. O Império Luso-Brasileiro (1500-1640) In: SERRÃO, Joel; MARQUES de Oliveira A. H. (Dirs.). Nova história da expansão portuguesa. Lisboa: Editorial Estampa, 1998.

KOSELLECK, Reinhart. Futuro passado: contribuição à semântica dos tempos históricos. Rio de Janeiro: Contraponto, PUC-Rio, 2006.

LEMANN, Nicholas. History solo: non-academic historians. The American Historical Review, v 1. 100, n.3, Jun., 1995.

LIPOVETSKY, Gilles. Metamorfoses da cultura liberal: ética, mídia, empresa. Porto Alegre: Editora Sulina, 2004.

MAGALHÃES, Joaquim Romero (Cord). Portugal no alvorecer da modernidade (14801620). In: MATTOSO, José (Dir). História de Portugal. Lisboa: Editora Estampa, 1997.

MALERBA, Jurandir. Acadêmicos na berlinda ou como cada um escreve a história: uma reflexão sobre o embate entre historiadores acadêmicos e não acadêmicos no Brasil à luz dos debates sobre a Public History. História da Historiografia, v. 15, p. 27-50, 2014.

MALERBA, Jurandir. (Org). História \& narrativa: a ciência e a arte da escrita da história. Petrópolis, RJ: Vozes. 2016. 
MOMIGLIANO, Arnaldo. As raízes clássicas da historiografia moderna. Bauru, SP: Edusc. 2004

MONTAIGNE, Michel de. Os ensaios. São Paulo: Pinguin Books, 2010.

MOREIRA, Fabiane Barbosa. Fato jornalístico e fato social. Em Questão, Porto Alegre, v. 10, n.2. p. 275-285, jul./dez., 2004.

NORA, Pierre. L'ère de la commémoration. In: NORA, Pierre. Les Lieux de mémoire. Paris: Gallimard, 1992/1997, v. 3 .

NOVAES, Ana Paula. Uma proposta polêmica: buscar um novo olhar par a História. Entrevista com Eduardo Bueno. Folha Dirigida. Suplemento Educação, 2010. Disponível em:

<http://www.folhadirigida.com.br/htmls/hotsites/suplemento_2007/Cad_06/Pag_63.html $>$. Acesso em 10/02/2010.

SERRÃO, Joel, MARQUES, Oliveira (Dir). Nova história da expansão portuguesa. Lisboa: Editorial Estampa, 1998.

PEREIRA, Mateus Henrique de Faria. A Máquina da memória: almanaque abril. O tempo presente entre a história e o jornalismo. Bauru, SP: Edusc. 2009.

RICOEUR, Paul. Ideologia y utopía. Editorial Gedisa. Barcelona, 1997.

ROCOEUR, Paul. A memória, a história, o esquecimento. Campinas, SP. Editora da Unicamp, 2007.

RÜDIGER, Francisco. Tendências do jornalismo. 3. ed. Porto Alegre: UFRGS Editora. 2003.

RÜSEN, Jörn. A razão histórica. Teoria da história: os fundamentos da ciência histórica. Brasília: Editora UNB, 2001.

SAMPAIO. Theodoro. História da Fundação da Cidade de Salvador. Bahia: Tipografia Beneditina LTDA, 1949.

SANTAYANA, Georges. The Life of reason or the phases of human progress: reason in common sense. New York:Scribner's, 1920 
SPENCER, Herbert. The Man Versus State. Nova Iorque: Mitchell Kennerley, 1912.

TEIXEIRA, Rosane Siqueira. Norteando o gosto do leitor: a indústria editorial e a coleção Terra Brasilis. 2001. Monografia (Especialização) - Curso de Educação, Faculdade de Ciências e Letras, Universidade Estadual Paulista Júlio de Mesquita Filho, Araraquara, 2001.

VLADO - 30 anos depois. Dir. e rot: João Batista de Andrade. Prod: Ariane Porto. Fotog.: João Batista de Andrade; Fabiano Pierri; Carlos Ebert; Edis Cruz. Dir.arte: Paulo Caetano. Ed.: Landa Costa. São Paulo: Oeste Filmes; TAO Produções, Europa Filmes, 2005. (86 min.) son, color.

WHITE, Hayden. Meta-história: a imaginação histórica do século XIX. São Paulo: Edusp, 1992.

WHITE, Hayden. The Content of the form: narrative discourse and historical representation. Baltimore and London: Johns Hopkins University Press, 1987.

WOLF, Mauro. Teorias das comunicações de massa. São Paulo: Martins Fontes, 2005. p 184.

YATES, Frances. A arte da memória. Campinas: Editora Unicamp. 2007

Recebido em 02/10/2016 Aprovado em 22/03/2017

Universidade do Estado de Santa Catarina - UDESC Programa de Pós-Graduação em História - PPGH

Revista Tempo e Argumento Volume 09 - Número 20 - Ano 2017 tempoeargumento@gmail.com 